\title{
Phytoremediation of Soils Contaminated with Aluminium and Manganese by Two Arbuscular Mycorrhizal Fungi
}

\author{
Elizabeth Alori ${ }^{1} \&$ Oluyemisi Fawole ${ }^{2}$ \\ ${ }^{1}$ Department of Soil Science, Landmark University, Omu-Aran, Nigeria \\ ${ }^{2}$ Department of Agronomy, University of Ilorin, Ilorin, Nigeria \\ Correspondence: Elizabeth Alori, Department of Soil Science, Landmark University, P. M. B, 1001, Omu-Aran, \\ Nigeria. Tel: 234-806-348-5837. E-mail:aloritope@yahoo.com
}

\author{
Received: April 24, 2012 Accepted: May 7, 2012 Online Published: July 27, 2012 \\ doi:10.5539/jas.v4n8p246 URL: http://dx.doi.org/10.5539/jas.v4n8p246
}

\begin{abstract}
Arbuscular Mycorrhizal Fungi (AMF) form symbiotic associations with the roots of many plants, and contribute to soil aggregation, structural stability and yield of plants in soils with low fertility. They have also been associated with cleaning of metal polluted soil. This study investigates the potential of AMF indigenous (Scutellospora reticulata and Glomus pansihalos) to Southern Guinea Savanna ecological zone of Nigeria to enhance phytoremediation of soils contaminated with Aluminium (Al) and Manganese (Mn). A 4x3x2 factorial pot experiment was used to assess the phytoremediation potential of indigenous AMF of alfisols contaminated with Al and $\mathrm{Mn}$ cropped with cowpea. The concentrations of the metals in soils and plants were determined by atomic absorption spectrophotometer. Data were analysed using Analysis of Variance (ANOVA). Both S. reticulata and G. pansihalos significantly reduced $\mathrm{Al}\left(\mathrm{F}_{5,21}=791.4 ; \mathrm{p}<0.05\right)$ and $\mathrm{Mn}\left(\mathrm{F}_{5,21}=286 ; \mathrm{p}<0.05\right)$ contents of soils polluted with these metals. $S$. reticulata however showed a significantly higher remediating ability than $G$. pansihalos. It was observed that soil properties had a significant impact on bioremediation by AM fungi. It was concluded that $S$. reticulata and G. pansihalos indigenous to southern Guinea savannah have the potential for use in phytoremediation of soils polluted with Aluminium and Manganese.
\end{abstract}

Keywords: indigenous, arbuscular mycorrhizas, phytoremediation, aluminium manganese, S. reticulata and G. pansihalos

\section{Introduction}

Crop productivity in the Southern Guinea Savanna agro ecological zone of Nigeria has reduced over the years due to soil related constrains. Some of these according to Sanchez et al. (2003) include: low soil moisture, low nutrient capital, erosion risk, low $\mathrm{pH}$, high phosphorus fixation, low levels of soil organic matter content, aluminium toxicity and loss of soil biodiversity. In the last century, Green Revolution Technology such as the use of pesticides, synthetic fertilizers and high yielding cultivars were used to overcome these constraints (Dalgaard et al., 2003). However, this technology increased natural resource degradation, raising question about sustainability of such agricultural practices according to these authors. In conventional high - input systems, the addition of agro-chemicals (such as fertilizers and pesticides) lead to continual disturbances to the soil system which affect both the abiotic and biotic soil factors with a resultant fact of long-term soil degradation (Bethlenfalvay \& Linderman, 1992).

The conventional systems of agriculture employed in advanced countries are too expensive for smallholder farmers in a developing country like Nigeria. Increasing and sustaining food production in ways that do not compromise environmental integrity and public health are major challenges (Tilman et al., 2002). For better soil nutrient management in Southern Guinea Savanna of Nigeria, an increase in use of biological systems are important. Data from literature have shown that heavy metals in soils cannot be chemically degraded and need to be physically removed or be immobilized (Kroopnick, 1994). Traditionally, remediation of heavy metal-contaminated soils involves either on-site management or excavation, and subsequent disposal to a landfill site (Parker, 1994). However, this method of disposal merely shifts the contamination problem elsewhere along with the hazards associated with transportation of contaminated soil and migration of contaminants from landfill into an adjacent environment (Williams, 1988). 
Arbuscular Mycorrhizal Fungi (AMF) constitute an important functional component of the soil -plant system that is critical for sustainable productivity in degraded soils (Gaur \& Adholeya, 2004). AMF are obligate symbionts of an estimated $80-90 \%$ of vascular plants and some nonvascular plants, such as mosses (Smith \& Read, 1997). Arbuscular Mycorrhizas have the ability to enhance host plant uptake of relatively immobile nutrients in particular $\mathrm{P}$ and several micronutrients (Cardoso \& Kuyper, 2006). They can restore the equilibrium of nutrient uptake that is misbalanced by heavy metals. (Carneiro et al., 2000). Jeffries et al. (2003) reported that Arbuscular mycorrhiza interacts with heavy metals, as such ameliorating the toxic effect of heavy metals and organic xenobiotics. They can also form an integral component of successful re-vegetated flue-gas desulphurization sludge ponds (Zhu \& Miller, 2003). As a result, AMF can accelerate re -vegetation of severely degraded lands such as coalmines or waste site containing high level of heavy metals. (Marx \& Altman, 1979).

A deeper knowledge of the dynamic relationships between agricultural practices, cultivated crops, soil pollutants, AMF and other soil biota is required for a successful transition from use of chemicals to natural methods, such as crop rotation and use of beneficial soil microorganism like AMF in crop production.

There is scarcity of information on the phyto-remediation potential of AMF indigenous to southern Guinea Savanna of Nigeria. This paper presents information on the potential of indigenous AMF in enhancing phytoremediation of soils contaminated with Aluminum and Manganese.

\section{Materials and Methods}

\subsection{Collection of Soil Samples}

Soil samples were collected randomly from four locations. Pategi \& Bacita soils which were formed over sedimentary rock and Malete \& Ilorin soils formed over basement complex in the southern Guinea savannah of Nigeria. All four soils used for the study are Alfisols. Using the random sampling method, auger samples were collected from each of the sampling units at $0-15 \mathrm{~cm}$. The soil samples collected from the four study sites were bulked and transported to the laboratory in well labelled polyethylene bags. The core samples were then air dried for 3 days and passed through $2 \mathrm{~mm}$ sieve in preparation for analysis.

\subsection{Extraction of AMF Spores}

AM spores were extracted using the wet- sieving and decanting/density gradient centrifugation method of Brundrett et al. (1996). Enumeration of spores was done under the dissecting microscope with magnification X40. The isolated spores were picked up with a needle under a dissecting microscope and were mounted in both polyvinyl alcohol lactic acid-glycerol (PVLG), Meltzer's reagent and PVLG mixed with Meltzer's reagent (1:1 $\mathrm{v} / \mathrm{v})$. All spores were examined using a compound microscope. Morphological properties of these spores were determined according to the key proposed by Trappe (1982). The characteristics used include, shape, size, colour, distinct wall layer, attached hyphae, sporocarps, bulbous attachment, clustering and surface ornamentation of spores. Spores were coated with gold to enhance observations under the scan electron microscope (SEM) at X 500. Identification was made by using the description provided by the international collection of vesicular and arbuscular mycorrhizal fungi (Invam, 2001).

The predominant AMF spores in all study sites, identified as Scutellospora reticulata and Glomus pansihalos were used for the study.

\subsection{Assessing the Potential of AMF for Enhancing Phytoremediation of Soils Contaminated with Aluminium and Manganese}

\subsubsection{Experimental Protocol}

The pot experiment was laid as a $4 \times 3 \times 2$ factorial experiment in a completely randomized design replicated thrice. The treatment combinations comprised soil from four sites; Ilorin, Malete, Pategi and Bacita, AM Fungal inoculums; (Scutellospora reticulata, Glomus pansihalos, un-inoculated) and two levels of Aluminum and Manganese $\left(50 \mathrm{mg}\right.$ and $100 \mathrm{mg} \mathrm{kg}^{-1}$ soil). Each pot was filled with $300 \mathrm{~g}$ of soil. Different Aluminum concentrations in the soil were obtained by adding aqueous solutions of Aluminium sulphate $\left\{\mathrm{Al}_{2}\left(\mathrm{SO}_{4}\right)_{3} .7 \mathrm{H}_{2} \mathrm{O}\right\}$, at $50 \mathrm{mgAl}$ and $100 \mathrm{mgAl} \mathrm{kg}^{-1}$ soil to soils in pots. Also manganese concentrates were obtained by adding aqueous solution of Manganese sulphate $\left\{\mathrm{MnSO}_{4} .5 \mathrm{H}_{2} \mathrm{O}\right\}$ at $50 \mathrm{mgMn}$ and $100 \mathrm{mgMn} \mathrm{kg}^{-1}$ soil to another set of pots. After carefully mixing the metal solutions with the soil, stability was allowed for 15 days before introduction of mycorrhizal inoculums. Cowpea (IT90K-82-2) (Please write down the origin) was used as the test crop

\subsubsection{Inoculation of Soils and Introduction of Test Plants}

One gram of the inoculum which consisted of soil with spores, hyphae and infected roots of maize plant was added to each pot at $3 \mathrm{~cm}$ depth and mixed with the soil. Uninoculated pots served as control for all treatments. Seeds of 
the test plant (Vigna unguiculata) L. (Walp.) were sterilized with hydrogen peroxide (10\%) for 30minutes and washed with sterile water. Three seeds were sown per pot and these were thinned to two per pot after germination. The plants were harvested at 8 weeks.

\subsubsection{Measurement of Heavy Metal Concentrations in Plant and Soils}

The roots and shoots from harvested plants were dried to constant weight at $65^{\circ} \mathrm{C}$. Dried plant materials and soils samples from various treatments were digested in $\mathrm{HNO} 3: \mathrm{HClO} 4$ (3:1). Aluminum and manganese in these extracts were then measured using Perkin - Elmer Atomic Absorption Spectrophotometer, model 303.

\subsubsection{Statistical Analysis}

Data collected were subjected to analysis of variance. Means were separated using Least Significant Difference (LSD), $\mathrm{p} \leq 0.05$.

\section{Results and Discussion}

\subsection{Effects of AM Fungi on Aluminium(Al) Polluted Soils}

The effects of AM fungi (Scutellospora reticulata and Glomus pansihalos) on Al polluted soils are reported in Table 1. Uninoculated soils had significantly higher levels of Al in both soil and shoot than the inoculated soils in the following order: Uninoculated-50mg Al kg-1 > Uninoculated-100mg Al kg-1 soil > G. pansihalos $100 \mathrm{mg}$ $\mathrm{Al} \mathrm{kg}{ }^{-1}$ soil $>$ S. reticulata $100 \mathrm{mg} \mathrm{kg}^{-1}$ soil $>$ G. pansihalos $50 \mathrm{mg} / \mathrm{kg}$ soil $>$ S. reticulata $50 \mathrm{mg} / \mathrm{kg}$ soil. (12.45, $15.62>3.56,5.69>3.76,6.09$ respectively in soil). This result showed that both $S$. reticulata and G. pansihalos have the ability to remediate soil polluted with Al. This is in line with the report of Newsham et al. (1995), that $\mathrm{AM}$ fungi can alleviate $\mathrm{Al}$ toxicity.

Table 1. Interactive Effects of AM Fungi and Aluminium levels on Al content in polluted soils and in cowpea plants

\begin{tabular}{llll}
\hline $\begin{array}{c}\text { AMF } \\
\text { Inoculation }\end{array}$ & Treatment (Al (mg kg-1 soil) $)$ & $\begin{array}{c}\mathrm{Al} \text { in soil } \\
(\mathrm{mg} \mathrm{kg}-1 \text { soil) }\end{array}$ & $\mathrm{Al}$ in shoot (mg kg-1 shoot) \\
\hline Uninoculated & $50 \mathrm{mg}$ & $12.45 \mathrm{~b}$ & $4.06 \mathrm{~b}$ \\
& 100 & $15.62 \mathrm{a}$ & $5.30 \mathrm{a}$ \\
S. reticulata & 50 & $3.56 \mathrm{e}$ & $1.83 \mathrm{e}$ \\
& 100 & $5.69 \mathrm{~cd}$ & $2.38 \mathrm{~cd}$ \\
G.pansihalos & 50 & $3.76 \mathrm{e}$ & $1.97 \mathrm{de}$ \\
& 100 & $6.09 \mathrm{c}$ & $2.50 \mathrm{c}$ \\
Mean & & 7.859 & 3.003 \\
Sed & & 0.2508 & 0.2064 \\
Lsd & & 0.5216 & 0.4292 \\
\hline
\end{tabular}

Means followed by the same letter (s) in column of any set of treatment are not significantly different at $5 \%$ level of probability using least significant difference (LSD) test.

When inoculated with $S$. reticulata, $\mathrm{Al}$ concentration in soil and shoot was lower at $50 \mathrm{mg} \mathrm{Al} \mathrm{kg}{ }^{-1}$ soil than at $100 \mathrm{mg} \mathrm{Al} \mathrm{kg}^{-1}$ soil. At $50 \mathrm{mg} \mathrm{Al} \mathrm{kg}^{-1}$ soil, Al concentration did not differ significantly, when inoculated with S.reticulata from when inoculated with G. pansihalos in both soil and shoot. However, at $100 \mathrm{mg} \mathrm{Al} \mathrm{kg}^{-1}$ soil, Al concentration was significantly lower in soil when inoculated with $S$. reticulata than when inoculated with $G$. Pansihalos, implying that $S$. reticulata remediates soil polluted with Al better than G. pansihalos.

\subsection{Effects of AM Fungi on Manganese (Mn) Polluted Soils}

Table 2 shows the effects of AMF on Mn levels in polluted soils and in shoot of cowpea. The concentrations of $\mathrm{Mn}$ in soil and shoot of cowpea in non-inoculated control were significantly higher than in soils inoculated with AMF and shoot of cowpea on polluted soils. This also indicates that AM fungi are capable of removing Mn from polluted soil. Nogueira and Cardoso (2000) reported that mycorrhizal soybeans (Glycine max (L) Merr.) grew better and had a lower concentration of $\mathrm{Fe}$ and $\mathrm{Mn}$ in the shoots than non-mycorrhizal soybeans. In the present study, there were no significant differences in Mn concentrations of soils polluted with $50 \mathrm{mg} \mathrm{Mn} \mathrm{kg}{ }^{-1}$ and those 
polluted with $100 \mathrm{mg} \mathrm{Mn} \mathrm{kg}^{-1}$ when treated with $S$. reticulata spores. However at $100 \mathrm{mg} \mathrm{Mn} \mathrm{kg}^{-1}$ soil in soils, $S$. reticulata significantly lowered Mn concentration than G. pansihalos. $\left(3.06 \mathrm{Mn} \mathrm{kg}^{-1}\right.$ soil and $3.50 \mathrm{mg} \mathrm{Mn} \mathrm{kg} \mathrm{moil}^{-1}$ respectively). This also points to the fact that $S$. reticulata remediates soil polluted with Mn better than $G$. pansihalos. Table 1 shows that shoot of cowpea cropped on soil polluted with $100 \mathrm{mg} \mathrm{Al} \mathrm{kg}^{-1}$ soil and treated with $G$. pansihalos had significantly lower Al (2.50 mg Al kg${ }^{-1}$ dry weight) than uninoculated control polluted with $100 \mathrm{mg} \mathrm{Al} \mathrm{kg}^{-1}$ soil (5.30mg Al kg${ }^{-1}$ dry weight). Table 2 also shows that shoot of cowpea on soil polluted with $100 \mathrm{mg} \mathrm{Mn} \mathrm{kg}^{-1}$ soil and treated with G. pansihalos had significantly lower Mn $\left(0.28 \mathrm{mg} \mathrm{Mn} \mathrm{kg}{ }^{-1} \mathrm{dry}^{-1}\right.$ weight) than uninoculated control polluted with $100 \mathrm{mg} \mathrm{Mn} \mathrm{kg}^{-1}$ soil (0.54mg Mn kg $\mathrm{mry}^{-1}$ weight).

Table 2. Interactive Effects of AM Fungi and Manganese levels on Mn content in polluted soils and in cowpea

\begin{tabular}{llll}
\hline $\begin{array}{l}\text { AMF Treatment } \\
\text { Inoculation }\end{array}$ & $\mathrm{Mn}\left(\mathrm{mg} \mathrm{kg}^{-1}\right.$ soil $)$ & $\mathrm{Mn}$ in soil $\left(\mathrm{mg} \mathrm{kg}^{-1}\right.$ soil $)$ & $\mathrm{Mn}$ in shoot $\left(\mathrm{mg} \mathrm{kg}^{-1}\right.$ shoot $)$ \\
\hline Uninoculated & 50 & $5.65 \mathrm{~b}$ & $0.42 \mathrm{ab}$ \\
& 100 & $6.46 \mathrm{a}$ & $0.54 \mathrm{a}$ \\
S. reticulata & 50 & $3.03 \mathrm{~d}$ & $0.18 \mathrm{c}$ \\
& 100 & $3.06 \mathrm{~d}$ & $0.21 \mathrm{c}$ \\
G. pansihalos & 50 & $3.11 \mathrm{~d}$ & $0.27 \mathrm{c}$ \\
& 100 & $3.50 \mathrm{c}$ & $0.28 \mathrm{bc}$ \\
Mean & & 4.128 & 0.317 \\
Sed & & 0.1275 & 0.0711 \\
Lsd & & 0.2651 & 0.1478
\end{tabular}

Means followed by the same letter (s) in column of any set of treatment are not significantly different at $5 \%$ level of probability using least significant difference (LSD) test.

This study has therefore shown that concentrations of $\mathrm{Al}$ and $\mathrm{Mn}$ in shoots of cowpea grown on mycorrhizal spores-treated soils were significantly lower than those cultivated on uninoculated controls. Nogueira et al. (2004) reported that increasing metal application rate led to increased uptake of the metals in shoots and increased retention in soil. S. reticulata \& G. pansihalos probably infected roots of cowpea and the mycorrhizal infection may have exerted some protective effect against $\mathrm{Al}$ and $\mathrm{Mn}$ accumulation in plants at the range of soil $\mathrm{Al}$ and $\mathrm{Mn}$ concentrations studied. The mycorrhizal roots may also have immobilized $\mathrm{Al}$ and $\mathrm{Mn}$ to some extent. This further implies that the ability of AMF to clean up a metal polluted soil may depend on the concentration of these metals. The higher the level of pollution, the higher the density of AM fungi required for remediation of such soil. Zhu et al. (2001) found out that increasing $\mathrm{Zn}$ application rate led to increased uptake of $\mathrm{Zn}$ in roots and shoots (especially roots) but the increases were significantly greater in non-mycorrhizal controls than in mycorrhizal treatments. According to Wang et al. (2006), heavy metal contents increased in soil, root, stem and leaves depending on the increased doses of $\mathrm{Cu}, \mathrm{Zn}$ and $\mathrm{Cd}$. The decreasing levels of metals in the shoots of test plants could be attributed to a corresponding reduction in soil concentrations. Joner et al. (2000) observed that Glomus mosseae was efficient in heavy metal adsorption. The G. mosseae strain was shown to transport cadmium $(\mathrm{Cd})$ from the soil into the fungal structures within the roots of clover. $\mathrm{Cd}$ was immobilized there and its transfer to the plant tissues was restricted (Joner \& Leyval, 1997). Wang et al. (2006) reported that a few AM fungal species belonging to the genera Glomus and Acalospora were found in soil contaminated with copper, zinc, lead and cadmium. Selvaraj and Challappan (2006) observed increase of tolerance to heavy metals in mycorrhizal plant than non inoculated plant.

\subsection{Amelioration of Manganese and Aluminium Pollution in Soils from Varying Sites by Indigenous AMF}

Table $3 \mathrm{a}$ and $3 \mathrm{~b}$ illustrate the interactive effects of soils from varying sites on amelioration of $\mathrm{Mn}$ and $\mathrm{Al}$ in polluted soils inoculated with AMF. Soils formed over basement complex (Ilorin and Malete) had significantly lower Al content than soils formed over sedimentary rock (Pategi and Bacita) (Table 3a). 
Table 3a. Interactive effects of varying soil sites, AM Fungi and Aluminium levels on Al content in polluted soils

\begin{tabular}{lccccccc}
\hline \multirow{2}{*}{$\begin{array}{l}\text { Treatment } \\
\mathrm{Al}\left(\mathrm{mg} \mathrm{kg}^{-1} \text { soil) }\right.\end{array}$} & Uninoculated & \multicolumn{3}{c}{ S. reticulata } & \multicolumn{3}{c}{ G.pansihalos } \\
\cline { 2 - 6 } Mean \\
\cline { 2 - 6 } Sites & 50 & 100 & 50 & 100 & 50 & 100 & \\
\hline Bacita & $19.92 \mathrm{a}$ & $22.70 \mathrm{a}$ & $4.29 \mathrm{a}$ & $7.90 \mathrm{a}$ & $4.81 \mathrm{~b}$ & $8.42 \mathrm{a}$ & 11.34 \\
Pategi & $11.51 \mathrm{~b}$ & $14.10 \mathrm{~b}$ & $3.26 \mathrm{a}$ & $6.27 \mathrm{~b}$ & $6.42 \mathrm{a}$ & $7.84 \mathrm{a}$ & 8.23 \\
Malete & $7.35 \mathrm{c}$ & $1.59 \mathrm{c}$ & $2.80 \mathrm{~b}$ & $4.81 \mathrm{c}$ & $4.28 \mathrm{~b}$ & $5.35 \mathrm{~b}$ & 6.03 \\
Ilorin & $11.01 \mathrm{~b}$ & $14.10 \mathrm{~b}$ & $1.01 \mathrm{c}$ & $2.74 \mathrm{~d}$ & $2.40 \mathrm{c}$ & $3.78 \mathrm{c}$ & 5.84 \\
Mean & 12.45 & 15.62 & 3.78 & 6.09 & 3.56 & 5.69 & 7.86 \\
\hline Sed & \multicolumn{7}{c}{0.5016} \\
\hline LSD
\end{tabular}

Means followed by the same letter (s) in column of any set of treatment are not significantly different at $5 \%$ level of probability using least significant difference (LSD) test

Table 3b. Interactive effects of varying soil sites, AM Fungi and Aluminium levels on Al content of shoot of cowpea cropped in Al polluted soil

\begin{tabular}{|c|c|c|c|c|c|c|c|}
\hline \multirow{2}{*}{$\begin{array}{l}\text { Treatment } \\
\mathrm{Al}\left(\mathrm{mg} \mathrm{kg}^{-1} \text { soil }\right)\end{array}$} & \multicolumn{2}{|c|}{ Uninoculated } & \multicolumn{2}{|c|}{ S. reticulata } & \multicolumn{2}{|c|}{ G.pansihalos } & \multirow{2}{*}{ Mean } \\
\hline & 50 & 100 & 50 & 100 & 50 & 100 & \\
\hline Sites & \multicolumn{7}{|c|}{ Shoot $\mathrm{Al}$ concentrations $(\mathrm{mg} / \mathrm{kg}$ ) } \\
\hline Bacita & $5.16 \mathrm{a}$ & $6.53 \mathrm{a}$ & $1.45 \mathrm{a}$ & $2.32 b$ & $2.46 \mathrm{a}$ & $3.52 \mathrm{a}$ & 3.58 \\
\hline Pategi & $3.52 \mathrm{~b}$ & $5.08 \mathrm{~b}$ & $1.97 \mathrm{a}$ & $3.22 \mathrm{a}$ & $2.48 \mathrm{a}$ & $3.24 \mathrm{ab}$ & 3.25 \\
\hline Malete & $5.06 \mathrm{a}$ & $6.10 \mathrm{a}$ & $1.46 \mathrm{a}$ & $1.76 \mathrm{bc}$ & $2.42 \mathrm{a}$ & $2.50 \mathrm{~b}$ & 3.22 \\
\hline Ilorin & $2.48 \mathrm{c}$ & $3.47 \mathrm{c}$ & $1.42 \mathrm{a}$ & $1.45 \mathrm{c}$ & $1.51 b$ & $1.48 \mathrm{c}$ & 1.97 \\
\hline Mean & 4.06 & 5.30 & 1.97 & 2.38 & 1.83 & 2.50 & 3.00 \\
\hline Sed & \multicolumn{7}{|c|}{0.4128} \\
\hline LSD & \multicolumn{7}{|c|}{0.8584} \\
\hline
\end{tabular}

Means followed by the same letter (s) in column of any set of treatment are not significantly different at $5 \%$ level of probability using least significant difference (LSD) test

Shoot of cowpea cropped on Ilorin soil polluted with Al had significantly lower Al with G.pansihalos and $S$. reticulata inoculants while Bacita soil had the highest Al levels (Table $3 \mathrm{~b}$ ).

Bacita soil had high Al and Mn contents. This could be due to the relatively high (9.2\%) clay content of Bacita soil (Olowonihi et al., 2011). The metals may have been adsorbed by the clay therefore, rendering them immobile. The ability of Ilorin soil to support amelioration of metals better may be as a result of its highest specie variety. The effect of soil type on Mn levels in polluted soils inoculated with AMF (Tables $4 \mathrm{a}$ and $4 \mathrm{~b}$ ) followed the same trend.

Ilorin soil had significantly lower Mn content while Bacita had the highest. This could also be due to the higher species variation in Ilorin soil and higher organic matter and clay content encountered in Bacita soil. Aluminium and Manganese levels were reduced with inoculation of AMF into soils from the four sites in the Southern Guinea Savannah used in this study. This further confirmed the potential of two indigenous AMF, G. pansihalos and S. reticulata to bioremediate soils of the Southerrn Guinea Savannah. 
Table 4a. Interactive effects of varying soil sites, AM Fungi and Manganese levels on Mn content in polluted soils

\begin{tabular}{|c|c|c|c|c|c|c|c|}
\hline \multirow{2}{*}{$\begin{array}{l}\text { Treatment } \\
\mathrm{Mn}_{\left(\mathrm{m} \mathrm{kg}^{-1}\right.} \text { soil) }\end{array}$} & \multicolumn{2}{|c|}{ Uninoculated } & \multicolumn{2}{|c|}{ S. reticulata } & \multicolumn{2}{|c|}{ G.pansihalos } & \multirow{2}{*}{ Mean } \\
\hline & 50 & 100 & 50 & 100 & 50 & 100 & \\
\hline Sites & \multicolumn{7}{|c|}{ Mn concentrations $(\mathrm{mg} / \mathrm{kg})$} \\
\hline Bacita & $6.16 \mathrm{~b}$ & $6.99 \mathrm{~b}$ & $3.47 \mathrm{a}$ & $4.27 \mathrm{a}$ & $3.97 \mathrm{a}$ & $4.72 \mathrm{a}$ & 4.93 \\
\hline Pategi & $6.12 \mathrm{~b}$ & $6.67 \mathrm{~b}$ & $3.27 \mathrm{a}$ & $3.04 \mathrm{~b}$ & $3.52 \mathrm{a}$ & $3.20 \mathrm{c}$ & 4.34 \\
\hline Malete & $7.47 \mathrm{a}$ & $8.66 \mathrm{a}$ & $3.47 \mathrm{a}$ & $3.00 \mathrm{~b}$ & $3.67 \mathrm{a}$ & $3.92 \mathrm{~b}$ & 5.03 \\
\hline Ilorin & $2.82 \mathrm{c}$ & $3.52 \mathrm{c}$ & $1.45 \mathrm{c}$ & $1.74 \mathrm{c}$ & $1.73 b$ & $1.97 \mathrm{~d}$ & 2.21 \\
\hline Mean & 5.65 & 6.46 & 3.03 & 3.50 & 3.11 & 3.02 & 4.13 \\
\hline Sed & \multicolumn{7}{|c|}{0.2550} \\
\hline LSD & & & & 0.5302 & & & \\
\hline
\end{tabular}

Means followed by the same letter (s) in column and row of any set of treatment are not significantly different at $5 \%$ probability using least significant difference (LSD) test.

Table 4b. Interactive effects of varying soil sites, AM Fungi and Manganese levels on Mn content of shoot of cowpea cropped in Mn polluted soils

\begin{tabular}{|c|c|c|c|c|c|c|c|}
\hline \multirow{2}{*}{$\begin{array}{l}\text { Treatment } \\
\mathrm{Mn}\left(\mathrm{mg} \mathrm{kg}^{-1} \text { soil) }\right.\end{array}$} & \multicolumn{2}{|c|}{ Uninoculated } & \multicolumn{2}{|c|}{ S. reticulata } & \multicolumn{2}{|c|}{ G.pansihalos } & \multirow{2}{*}{ Mean } \\
\hline & 50 & 100 & 50 & 100 & 50 & 100 & \\
\hline Sites & \multicolumn{7}{|c|}{ Shoot Mn contentrations (mg/kg) } \\
\hline Bacita & $0.50 \mathrm{a}$ & $0.43 b$ & $0.23 \mathrm{a}$ & $0.20 \mathrm{a}$ & $0.39 \mathrm{a}$ & $0.21 \mathrm{~b}$ & 0.33 \\
\hline Pategi & $0.34 \mathrm{a}$ & $0.34 \mathrm{~b}$ & $0.16 \mathrm{a}$ & $0.14 \mathrm{a}$ & $0.23 \mathrm{a}$ & $0.17 \mathrm{~b}$ & 0.23 \\
\hline Malete & $0.54 \mathrm{a}$ & $0.89 \mathrm{a}$ & $0.23 \mathrm{a}$ & $0.23 \mathrm{a}$ & $0.36 \mathrm{a}$ & $0.53 \mathrm{a}$ & 0.46 \\
\hline Ilorin & $0.29 \mathrm{a}$ & $0.49 b$ & $0.11 \mathrm{a}$ & $0.22 \mathrm{a}$ & $0.12 \mathrm{a}$ & $0.25 \mathrm{ab}$ & 0.46 \\
\hline Mean & 0.42 & 0.54 & 0.27 & 0.28 & 0.18 & 0.21 & 0.32 \\
\hline Sed & \multicolumn{7}{|c|}{0.1422} \\
\hline LSD & \multicolumn{7}{|c|}{0.2956} \\
\hline
\end{tabular}

Means followed by the same letter (s) in column and row of any set of treatment are not significantly different at $5 \%$ level of probability using least significant difference (LSD) test.

\section{Conclusions}

This study has further established mycorrhizal technology as an important consideration in bioremediation of agricultural soils. AMF had a significant impact in cleaning up Al and Mn from polluted soil. Both indigenous AMF, S. reticulata and G. pansihalos, used in the study exhibited the ability to remediate soils contaminated with $\mathrm{Al}$ and Mn. S. reticulata however showed a significantly higher remediating ability than G. pansihalos. Soil properties have a significant impact on bioremediation by AM fungi. The indigenous AM fungi are potential biotechnological tools for inoculation of plants for successful restoration of ecosystem polluted with heavy metals. They should be paid due attention to increase, restore or manage soil fertility.

\section{References}

Bethlenfalvay, G. J., \& Linderman, R. G. (1992). Preface. In Mycorrhizae in Sustainable Agriculture. Eds. G. J. Bethlenfalvay \& R. G. Linderman. pp viii-xiii. American Society of Agronomy, Inc., Crop Science Society of America, Inc., Soil Science Society of America, Inc., Madison, WI, USA.

Brundrett, M., Bougher, N., Dell, B., Grove, T., \& Malajczuk, N. (1996). Working with mycorrhizas in forestry and agriculture. Australian Centre for International Agricultural Research Monograph, 32, 374.

Cardoso, I. M., \& Kuyper, T. W. (2006). Mycorrhizas and Tropical soil fertility. Agriculture, Ecosystem and Environment, 116, 72-84. http://dx.doi.org/10.1016/j.agee.2006.03.011

Carneiro, M. A. C., Siqueira, J. O., \& Moreira, F. M. D. (2000). Estabelecimento de plantas herbaceas em solo com contaminacao de metais pesadoes e inoculacao de fungos micorrizicos arbusculares. Pesquisa agropecuaria. Brasileira, 36, 1443-1452.

Dalgaard, T., Hutchings, N. J., \& Porter, J. R. (2003). Agroecology, scaling and interdisciplinarity. Agriculture, Ecosystems and Environment, 100, 39-51. http://dx.doi.org/10.1016/S0167-8809(03)00152-X 
Gaur, A., \& Adholeya, A. (2004). Prospect of arbuscular mycorrhizal fungi in phytoremediation of heavy metal contaminated soils. Current Science, 86(4), 528-534. http://cat.inist.fr/?aModele=afficheN\&cpsidt=16114013

Jeffries, P., Gianinazzi, S., Perotto, S., Turnau, K., \& Barea, J. (2003). The contribution of arbuscular mycorrhizal fungi in sustainable maintenance of plant health and soil fertility. Biology and Fertility of Soils, 37, 1-16. http://dx.doi.org/10.1007/s00374-002-0546-5

Joner, E. J., \& Leyval, C. (1997). Uptake of ${ }^{109} \mathrm{Cd}$ by roots and hyphae of Glomus mosseae (Trifolium subterraneum) mycorrhizae from soil amended with high and low concentration of cadmium. New Phytology 135, 353-360. http://dx.doi.org/10.1046/j.1469-8137.1997.00633.x

Joner, E. J., Leyval, C., \& Briones, R. (2000). Metal-binding capacity of arbuscular mycorrhizal hydrocarbons. Biology and Fertility of Soils, 226, 227-234.

Kroopnick, P. M. (1994). Vapor abatement costs analysis methodology for calculating life cycle costs for hydrocarbon vapour extracted during soil venting. Remediation of hazardous waste. Wise, D. L., Trantolo, D. J. (Eds) Marcel Dekker, New York, pp. 779-790.

Marx, D. H., \& Altman, J. D. (1979). Pisolithus tinctorius ectomycorrhizal improve survival and growth of pine seedlings on acid coal spoil in Kentucky and Virginia. Mycorrhizal manual, Springer, Berlin. pp. 387-399.

Newsham, K. K., Filter, A. H., \& Watkinson, A. R. (1995). Multifunctionaity and biodiversity in arbuscul mycorrhizas. Trends in Ecology and Evolution, 10, 407-411. http://dx.doi.org/10.1016/S0169-5347(00)89157-0

Nogueira, M. A., \& Cardoso, E. J. B. N. (2000). Producao de micelio externo por fungos micorrizico arbusculares e crescimento da soja em funcao de doses de fosforo. Revista Brasileira de Ciecia do Solo, 17, 329-338. http://www.scielo.br/scielo.php?script=sci_serial\&pid=0100-0683\&lng=en\&nrm=iso

Nogueira, M. A., Magelhaes, G. C., \& Cardoso, E. J. B. N. (2004). Manganese toxicity in mycorrhizal and phosphorus-fertilized soybean plants. Journal of Plant Nutrition, 27, 141-156. http://dx.doi.org/10.1081/PLN-120027552

Olowonihi, E. T., Fawole, O. B., \& Afolayan, A. J. (2011). Arbuscular Mycorrhizal Fungi in Southern Guinea Savanna of Nigeria. Germany LAP LAMBERT Academic Publishing GmbH \& Co.

Parker, R. (1994). Environmental Restoration technologies. EMIAA yearbook. pp. 169- 171.

Sanchez, P. A., Palm, C. A., \& Buol, S. W. (2003). Fertility capacity, soil classification: a tool to help assess soil quality in the tropics. Geoderma, 114, 157-185. http://dx.doi.org/10.1016/S0016-7061(03)00040-5

Selvaraj, T., \& Challappan, P. (2006). Mycorrhizae: A Diverse personality. Journal of Central European Agriculture, 7(2), 349-358. http://hrcak.srce.hr/file/26831

Smith, S. E., \& Read, D. J. (1997). Mycorrhizal symbiosis. Academic Press, London. http://dx.doi.org/10.1046/j.14698137.1997.00851-2.x

Tilman, D., Cassman, K. G., Matson, P. A., Nylor, R., \& Polasky, S. (2002). Agricultural sustainability and intensive production practices. Nature, 418, 671-677. http://dx.doi.org/10.1038/nature01014

Wang, F., Lin, X., Yin, R., \& Wu, L. (2006). Effects of arbuscular mycorrhizal inoculation on the growth of Elsholtzia splendens and Zea mays L. and the activities of phosphatase and urease in a multi-metal contaminated soil under unsterilized conditions. Applied Soil Ecology, 31(1-2), 110-119. http://dx.doi.org/10.1016/j.apsoil.2005.03.002

Williams, G. M. (1988). Integrated studies into ground water pollution by hazardous wastes. Land Disposal of Hazardous waste, Engineering and Environmental issues Gronow, J. R., Schofield, A. N., Jain, R. K. (Eds), Horwood Ltd, Chichester, UK.

Wilson, G. W. T., Hetrick, B. A. D., \& Schwab, A. P. (1991). Reclamation effects on mycorrhizae and productive capacity of flue gas desulfurization sludge. Journal of Environmental Quality, 20, 777-783. http://dx.doi.org/10.2134/jeq1991.00472425002000040011x

Zhu, Y. G., \& Miller, R. M. (2003). Carbon cycling by arbuscular mycorrhizal fungi in soil - plant systems. Trends in Plant Science, 8, 407-409. http://dx doi:10.1016/S1360-1385(03)00184-5

Zhu, Y. G., Christie, P., \& Laidlaw, A. S. (2001). Uptake of Zn by arbuscular mycorrhizal white clover from Zncontaminated soil. Chemosphere, 4, 193-199. http://dx.doi.org/10.1016/S0045-6535(00)00125-9 